University of Nebraska - Lincoln DigitalCommons@University of Nebraska - Lincoln

USDA National Wildlife Research Center - Staff U.S. Department of Agriculture: Animal and Plant Publications Health Inspection Service

2012

\title{
Winter and Summer Home Ranges and Core Use Areas of Double-crested Cormorants Captured near Aquaculture Facilities in the Southeastern United States
}

D. Tommy King

USDA/APHIS/WS National Wildlife Research Center, tommy.king@aphis.usda.gov

Bronson K. Strickland

Mississippi State University

Andrew A. Radomski

U.S. Department of Agriculture

Follow this and additional works at: https://digitalcommons.unl.edu/icwdm_usdanwrc

Part of the Life Sciences Commons

King, D. Tommy; Strickland, Bronson K.; and Radomski, Andrew A., "Winter and Summer Home Ranges and Core Use Areas of Double-crested Cormorants Captured near Aquaculture Facilities in the Southeastern United States" (2012). USDA National Wildlife Research Center - Staff Publications. 1503.

https://digitalcommons.unl.edu/icwdm_usdanwrc/1503

This Article is brought to you for free and open access by the U.S. Department of Agriculture: Animal and Plant Health Inspection Service at DigitalCommons@University of Nebraska - Lincoln. It has been accepted for inclusion in USDA National Wildlife Research Center - Staff Publications by an authorized administrator of DigitalCommons@University of Nebraska - Lincoln. 


\title{
Winter and Summer Home Ranges and Core Use Areas of Double-crested Cormorants Captured near Aquaculture Facilities in the Southeastern United States
}

\author{
D. Tommy King ${ }^{1, *}$, Bronson K. Strickland ${ }^{2}$ and Andrew A. Radomski ${ }^{3}$ \\ ${ }^{1}$ U.S. Department of Agriculture, Wildlife Services, National Wildlife Research Center, Mississippi State, \\ MS, 39762, USA
}

\begin{abstract}
${ }^{2}$ Mississippi State University, Department of Wildlife \& Fisheries, Box 9690, Mississippi State, MS, 39762, USA
${ }^{3}$ U.S. Department of Agriculture, Agricultural Research Service, H. K. Dupree Stuttgart National Aquaculture Research Center, P.O. Box 1050, Stuttgart, AR, 72160, USA

*Corresponding author; E-mail: Tommy.King@aphis.usda.gov
\end{abstract}

\begin{abstract}
Numbers of Double-crested Cormorants (Phalacrocorax auritus) wintering in the southeastern United States have increased dramatically during the last 30 years concomitant with the rise of the aquaculture industry in this region. These cormorants commonly foraged at commercial aquaculture facilities and thereby came into conflict with farmers. Various interest groups are seeking ecologically sound strategies for minimizing the effects of burgeoning cormorant populations. Therefore, this study was conducted to estimate winter and summer home ranges of cormorants captured in the southeastern U.S. and determine whether age class, body mass, density of aquaculture facilities and availability of roost sites influenced size of these home ranges. Mean \pm SE home range size and core use area of satellite transmitter-marked cormorants wintering in the southeastern U.S. from 1999 to 2001 were $17,490 \pm 1,986 \mathrm{~km}^{2}(\mathrm{~N}=37)$ and $1,550 \pm 265 \mathrm{~km}^{2}(\mathrm{~N}=37)$, respectively. Winter home range size was not affected by region, age class or body mass. Summer home range and core use area of marked cormorants was 30,547 $\pm 6,197 \mathrm{~km}^{2}(\mathrm{~N}=6)$ and 3,124 $\pm 1,019 \mathrm{~km}^{2}(\mathrm{~N}=6)$, respectively. Received 28 September 2007, accepted 1 November 2009.

Key words.-aquaculture, Double-crested Cormorant, home range, movements, Phalacrocorax auritus, platform transmitter, PTT, satellite telemetry, summer, winter.
\end{abstract}

Waterbirds 35(Special Publication 1): 124-131, 2012

Numbers of Double-crested Cormorants (Phalacrocorax auritus, hereafter cormorants) wintering in the southeastern United States have increased dramatically during the last 30 years concomitant with the rise of the aquaculture industry in this region (Glahn and Stickley 1995; Glahn and King 2004). These cormorants commonly forage at commercial aquaculture facilities and thereby come into conflict with farmers (Glahn et al. 1995; King et al. 1995; Glahn and King 2004). Glahn et al. (2000) estimated that cormorant predation on Channel Catfish (Ictalurus punctatus) costs the Mississippi aquaculture industry up to $\$ 25$ million annually.

In addition to southeastern aquaculture producers, sport and commercial fishermen in the Great Lakes and Northeastern Regions have become concerned about increasing cormorant numbers (VanDeValk et al. 2002; Rudstam et al. 2004). The various interest groups involved are seeking ecologically sound strategies for mitigating the effects of burgeoning cormorant populations.
Previous VHF telemetry studies have provided useful information about local movements and behavior of cormorants wintering in the Alluvial Valley of Mississippi and the Upper Coastal Plain of east-central Mississippi and west-central Alabama (King et al. 1995; King 1996; Tobin et al. 2002; Dorr et al. 2004). However, cormorant home range and core use areas, the effects of age, density of aquaculture facilities, or availability of roost sites on cormorant home ranges have not been studied (Hatch and Weseloh 1999). The Alluvial Valley of Mississippi alone has a much higher density of aquaculture $(40,000$ ha; USDA 1999), and cormorant night roosts $(\mathrm{N}=39)$ than does the Upper Coastal Plain of east-central Mississippi and west-central Alabama (11,900 ha; USDA 1999; $\mathrm{N}=19$ roosts; Tobin et al. 2002; Dorr et al. 2004). Although radio telemetry has provided daily information on transmitter-equipped birds, the logistic constraints involved with the utilization of VHF telemetry preclude its use in effectively addressing larger-scale regional 
and continental questions concerning cormorant movements.

Satellite transmitters (Platform Transmitter Terminals, PTT) have been used to monitor the movements of many large mammals and some large migratory birds. Recent technology advances have allowed the development of satellite transmitters small enough to be used on cormorants. The use of satellite telemetry will provide much needed information on the local, regional and continental movements of cormorants and will help researchers better evaluate current control methods and develop ecologically sound control strategies.

The objectives of this study were to: 1 ) estimate winter and summer home ranges and core use areas of cormorants marked near southeastern aquaculture facilities; 2) compare winter home ranges and core use areas of cormorants captured in the Mississippi Alluvial Valley of Arkansas, Louisiana and Mississippi (more numerous ponds and roost sites) vs. those captured in the Upper Coastal Plain of Alabama (fewer ponds and roost sites); and 3) determine if body mass of cormorants affects home range size and core use area.

\section{Methods}

\section{Study Site}

The study area comprised the Mississippi River Alluvial Valley (MAV) regions of southeastern Arkansas, northeastern Louisiana, and northwestern Mississippi and the Upper Coastal Plain (UCP) of the TennesseeTombigbee and Alabama River Valleys in eastern Mississippi and western Alabama (Fig. 1). Cormorants were captured in nine winter night roosts (King et al. 1994) near aquaculture-intensive areas from November 1999 through February 2001. Cormorants were fitted with satellite PTTs using a backpack harness (Dunstan 1972; King et al. 2000) and released in the capture roost. The gender of captured cormorants was not determined. The age of each captured cormorant was estimated based on plumage. A bird with light-tan chest and neck feathers was classified as immature, and a black bird was classified as an adult (Palmer 1962).

This research was conducted under the following permits: US Department of Agriculture, Wildlife Services, National Wildlife Research Center's Institutional Animal Care and Use Committee Protocol QA-742 and US Department of Interior, US Geological Survey, Federal Bird Banding Permit 20873.

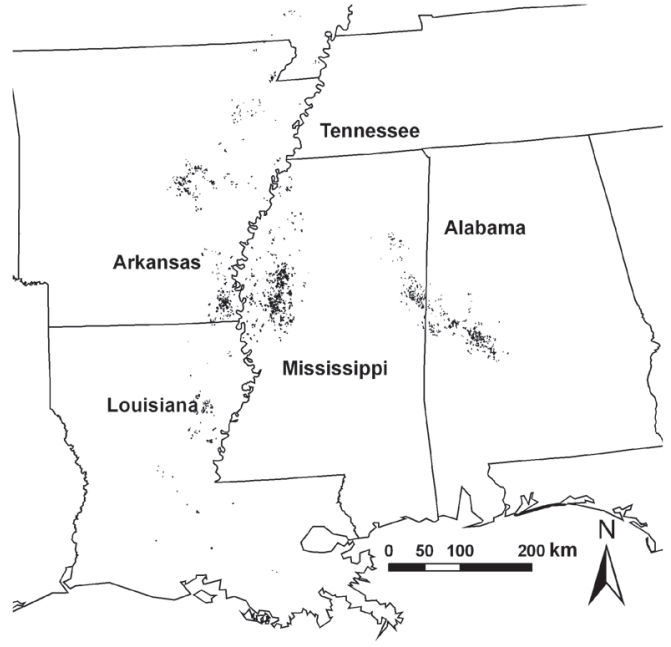

Figure 1. Locations of catfish aquaculture facilities in the Mississippi Alluvial Valley of Arkansas, Mississippi, and Louisiana and the Upper Coastal Plain physiographic regions of Alabama and Mississippi.

\section{PTT Duty Cycles}

During the winter of 1999-2000, 45-g PTTs were programmed to transmit for eight hours every $48 \mathrm{~h}$ from October through May, and eight hours every ten days from June through September. Microwave Telemetry, Inc. (Columbia, MD) subsequently reduced the weight and increased battery life of their small PTTs. Thus, during the winter of 2000-2001, 30-g PTTs were programmed to transmit for six hours every $48 \mathrm{~h}$ from October through mid-June and six hours every ten days from mid-June through September. Using this programming, the expected longevity of the PTTs was twelve months. Service Argos, Inc. (2001) provided data on the locations of the PTTs. Location error was reported by Service Argos, Inc. (2001) as one of six location classes (LC): LC3 $=<150 \mathrm{~m}, \mathrm{LC} 2=150$ to $<350 \mathrm{~m}$, LC1 $=350$ to $\leq 1000 \mathrm{~m}, \mathrm{LC} 0=>1000 \mathrm{~m}, \mathrm{LCA}$ and $\mathrm{LCB}=$ no estimate of location accuracy.

\section{Statistical Analyses}

Douglas' (2000) PC-SAS ARGOS Filter Version 2.4 was used to parse and filter data obtained from Service Argos, Inc. A flight distance of $\leq 200 \mathrm{~km} /$ day and speed of $\leq 50 \mathrm{~km} / \mathrm{h}$ were used for two LC filters: 1) a user-defined distance to determine location redundancy, and 2) distance, angle, and rate measurements designed to remove illogical locations. After filtering, location data were plotted and analyzed using ArcGIS 9 (Environmental Systems Research Institute, Inc., Redlands, CA).

Winter (November to February) and summer (June to August) utilization distributions were calculated (Worton 1989) from locations of cormorants during daytime $(07.00$ to $17.00 \mathrm{~h}$ and 07.00 to $18.00 \mathrm{~h}$ for winter and summer, respectively) using an adaptive-kernel estimator with the reference bandwidth $\left(h_{\text {ref }}\right)$. Ninety- 
five percent winter and summer home ranges and $50 \%$ winter and summer core use areas of PTT-marked cormorants were calculated using the Home Range Extension for ArcGIS ${ }^{\circledR}$ (Rodgers et al. 2005) in ESRI ${ }^{\circledR}$ ArcMap $^{\mathrm{TM}} 9.1$ software.

Some researchers favor the fixed-kernel estimator with least squares (see Horne and Garton 2006); however, earlier analyses demonstrated multiple discontinuous use areas using the fixed-kernel estimator with our data (i.e. discontinuous use area derived from one observation peripheral to the center of activity). Thus, based on the distribution patterns observed in our data we elected to use the adaptive-kernel estimator with the reference bandwidth $\left(h_{\text {ref }}\right)$ to generate more continuous home range areas (Kernohan et al. 2001, p. 146).

Although $\geq 50$ samples has been suggested as a minimum for kernel home range estimation by some researchers (Kernohan et al. 2001), this sample size would have eliminated $>50 \%$ of PTT-marked cormorants from the analysis. Instead, cormorants with $\geq 20$ location samples were used for the analysis. The effect of sample size and number of study days on home range size was tested using correlation to determine whether the lesser number of samples (i.e. <50) biased the utilization distribution estimates. Sample size $(r=$ $0.15, \mathrm{P}=0.38)$ and number of study days $(r=0.24$, $\mathrm{P}=0.22)$ were not associated with estimated home range size. Thus, estimates of home range and core use based on $\geq 20$ observations were believed to accurately depict the movement patterns of cormorants in the study areas.

In four cases, distinct shifts were evident in the center of activity of cormorants. The locations of cormorants outside of their center of activity were not included to ensure that home range and core use areas were not artificially increased. Thus, for three cormorants, only observations $(\mathrm{N} \geq 20)$ surrounding their center of activity were included. One cormorant had $>20$ observations for both centers of activity, so two home range and core areas were calculated for that individual.

Home range of cormorants in the MAV region was hypothesized to be smaller due to the greater number of aquaculture facilities, thus providing more foraging areas closer to day and evening roost sites (King et al. 1995; King 1996). Further, age class (adult vs. immature) was hypothesized to possibly influence home range size. Older cormorants were predicted to occupy the best foraging areas (smaller home ranges) and relegate younger, subordinate cormorants to lower-quality foraging areas (larger home ranges). Thus, the effects of region (MAV vs. UCP) and age class (adult vs. immature) and the region-by-age class interaction on home range size and core use area of PTT-marked cormorants were tested using analysis of variance (ANOVA). Because variances among region and age class groups were not equal, a heterogeneous variance model structure (Littell et al. 2006) was incorporated using the MIXED procedure in SAS (SAS Institute Inc., 2004). With this model structure, a different variance is estimated for each group in the ANOVA, rather than transforming the data for analysis. Furthermore, F-test degrees of freedom were corrected for unbalanced variances using the Kenward and Roger adjustment (Littell et al. 2006).

Lastly, body mass was hypothesized to affect home range size of cormorants. Although relationships between body size and space use are typically conducted at the species level (Schoener 1968; Harestad and Bunnell 1979), we were interested in knowing whether body size might covary with dominance and influence the quality size of foraging areas. To determine whether body mass influenced the spatial use patterns of PTT-marked cormorants during winter, the body mass of cormorants at the time of capture was related to home range size and core use area using Pearson's correlation coefficient. Significance of all hypothesis tests were assessed using $\alpha=0.05$.

\section{RESULTS}

Mean \pm SE home range size and core use area of PTT-marked cormorants wintering in the southeastern U.S. from 1999 to 2001 were $17,490 \pm 1,986 \mathrm{~km}^{2}(\mathrm{~N}=37)$ and 1,550 $\pm 265 \mathrm{~km}^{2}(\mathrm{~N}=37)$, respectively (Table 1$)$. Home range size was highly variable among individuals during winter (Fig. 2), but was not affected by region $\left(F_{1,263}=0.82, \mathrm{P}=\right.$ $0.440)$, age class $\left(F_{1,2.63}=1.66, \mathrm{P}=0.299\right)$, or their interaction $\left(F_{1,2.63}=0.63, \mathrm{P}=0.491\right.$; Table 2). Similarly, core use area was not affected by region $\left(F_{1,2.31}=0.86, \mathrm{P}=0.439\right)$, age class $\left(F_{1231}=1.08, \mathrm{P}=0.395\right)$, or their interaction $\left(F_{1,2.31}=0.40, \mathrm{P}=0.582\right.$; Table 2$)$. Winter home range size $(r=-0.19, \mathrm{P}=0.259)$ and core use area $(r=-0.15, \mathrm{P}=0.372)$ were not correlated to body mass of cormorants. Mean home range size and core use area of PTT-marked cormorants during summer from 1999 to 2001 was $30,547 \pm 6,197 \mathrm{~km}^{2}$ (N $=6)$ and $3,124 \pm 1,019 \mathrm{~km}^{2}(\mathrm{~N}=6)$, respectively (Table 3, Fig. 3).

\section{Discussion}

The winter home ranges reported in this study are more than double the size of the $95 \%$ home range $\left(4,609 \mathrm{~km}^{2}\right)$ and the $50 \%$ core use area $\left(566 \mathrm{~km}^{2}\right)$ reported by Dorr et al. (these proceedings) for eastern Lake Ontario cormorants $(\mathrm{N}=6)$ wintering in the southeastern U.S. The reason for this difference is unclear but may have been influenced by the number of observations used to compute each cormorant's home range in 
Table 1. Daytime (07.00-18.00 h) home range (95\% kernel) and core use areas $(50 \%$ kernel) of 14 adult and 23 immature (Imm) Double-crested Cormorants marked with Platform Transmitter Terminals PTT transmitters in the Mississippi alluvial valley (MAV) of Arkansas, Louisiana, and Mississippi and the Upper Coastal Plain (UCP) of Alabama during winter (November to February) from 1999 to 2001 . $\mathrm{N}$ = number of locations.

\begin{tabular}{|c|c|c|c|c|c|}
\hline Cormorant & Age class & Capture region & $\mathrm{N}$ & Home range $\left(\mathrm{km}^{2}\right)$ & Core use area $\left(\mathrm{km}^{2}\right)$ \\
\hline 002 & $\mathrm{Imm}$ & MAV & 56 & 24,862 & 1,052 \\
\hline 004 & $\mathrm{Imm}$ & MAV & 59 & 24,130 & 2,266 \\
\hline 005 & Adult & MAV & 31 & 17,978 & 989 \\
\hline 006 & $\mathrm{Imm}$ & MAV & 24 & 15,547 & 2,419 \\
\hline 007 & $\mathrm{Imm}$ & MAV & 24 & 16,494 & 1,266 \\
\hline 009 & $\mathrm{Imm}$ & MAV & 53 & 21,296 & 914 \\
\hline 011 & $\mathrm{Imm}$ & MAV & 44 & 26,793 & 1,872 \\
\hline 012 & Adult & MAV & 122 & 38,212 & 1,900 \\
\hline 013 & Adult & UCP & 39 & 29,729 & 3,646 \\
\hline 014 & $\mathrm{Imm}$ & UCP & 51 & 57,998 & 9,612 \\
\hline 015 & $\mathrm{Imm}$ & MAV & 24 & 10,852 & 828 \\
\hline 016 & $\mathrm{Imm}$ & MAV & 31 & 12,007 & 1,586 \\
\hline 017 & Imm & MAV & 22 & 16,209 & 1,809 \\
\hline 018 & $\mathrm{Imm}$ & UCP & 24 & 39,680 & 2,047 \\
\hline 020 & Adult & UCP & 22 & 8,985 & 979 \\
\hline 021 & Adult & UCP & 20 & 6,671 & 371 \\
\hline 022 & $\mathrm{Imm}$ & MAV & 25 & 16,985 & 1,664 \\
\hline 023 & Adult & MAV & 21 & 9,489 & 1,272 \\
\hline 026 & $\mathrm{Imm}$ & MAV & 25 & 14,805 & 1,024 \\
\hline 027 & $\mathrm{Imm}$ & MAV & 20 & 8,924 & 743 \\
\hline 031 & $\mathrm{Imm}$ & UCP & 133 & 1,435 & 57 \\
\hline 032 & Adult & UCP & 98 & 12,144 & 497 \\
\hline 033 & $\mathrm{Imm}$ & MAV & 150 & 40,834 & 3,351 \\
\hline 034 & Adult & MAV & 181 & 12,722 & 489 \\
\hline 035 & $\mathrm{Imm}$ & MAV & 81 & 14,629 & 922 \\
\hline 036 & Adult & MAV & 161 & 10,128 & 1,182 \\
\hline 037 & Adult & MAV & 72 & 9,244 & 983 \\
\hline 039 & Adult & MAV & 23 & 2,639 & 201 \\
\hline 042 & $\mathrm{Imm}$ & MAV & 35 & 4,206 & 401 \\
\hline 043 & Imm & MAV & 21 & 11,832 & 1,838 \\
\hline 046 & $\mathrm{Imm}$ & MAV & 24 & 14,538 & 1,347 \\
\hline 047 & Imm & MAV & 24 & 10,446 & 728 \\
\hline 048 & $\mathrm{Imm}$ & MAV & 24 & 26,575 & 3,267 \\
\hline 049 & $\mathrm{Imm}$ & MAV & 53 & 24,481 & 1,524 \\
\hline 050 & Adult & MAV & 21 & 5,022 & 456 \\
\hline $38 \mathrm{~N}$ & Adult & MAV & 61 & 22,820 & 1,264 \\
\hline $38 \mathrm{~S}$ & Adult & MAV & 35 & 5,789 & 566 \\
\hline Mean & & & & 17,490 & 1,550 \\
\hline SE & & & & 1,986 & 265 \\
\hline
\end{tabular}

the study by Dorr et al. and thus the use of fixed-kernel versus adaptive-kernel estimators for home range analyses. Because the local bandwidth in the adaptive-kernel estimator can be greater in areas with few observations (Kernohan et al. 2001), this estimator may have produced larger home ranges than a fixed-kernel estimator, as used by Dorr et al. (these proceedings). Another possible reason may be that eastern Lake Ontario cormorants belong to the Atlantic meta-population rather than the Interior meta-population. Only one bird from this study had a summer home range east of central Lake Ontario. Tyson et al. (1999) described the eastern boundary of the Interior meta-population as occurring in the extreme eastern part of Lake Ontario. However, researchers now speculate that the boundaries of the Interior meta-population of cormorants should be shifted due to range expansion (Hatch and Weseloh 1999; Chastant 2008).

The similar home range sizes of immature and adult cormorants using the MAV or UCP indicate that irrespective of age, body mass or location, cormorants will utilize a 
A.

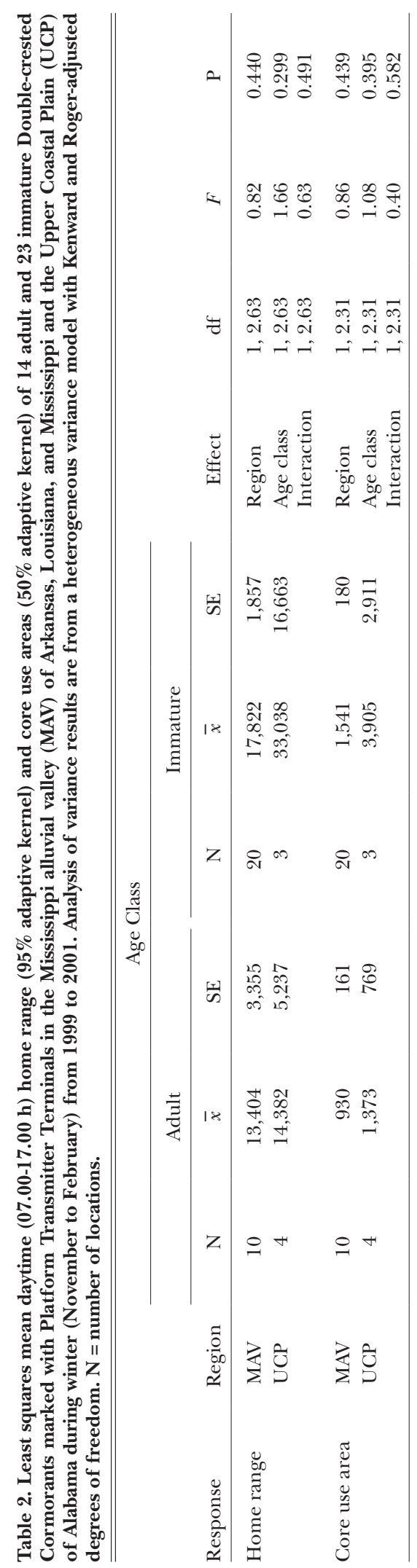

Figure 2. Examples of winter (November to February) daytime (07.00-17.00 h) $95 \%$ adaptive kernel home ranges (light shading) and $50 \%$ adaptive kernel core use areas (dark shading) of Double-crested Cormorants marked with Platform Transmitter Terminals in the Mississippi Alluvial Valley of Arkansas, Louisiana, and Mississippi and the Upper Coastal Plain of Alabama from 1999 to 2001. A) Home ranges $<10,000 \mathrm{~km}^{2}(\mathrm{~N}=$ 7 ), and $B$ ) home ranges $>20,000 \mathrm{~km}^{2}(\mathrm{~N}=5)$. Numbers represent bird identification.

range size necessary to meet their energetic and social requirements. The cause for the extent of individual variation in home range size (range $=1,435$ to $57,998 \mathrm{~km}^{2}$; Fig. 2) among marked cormorants may have been due to gender or a gender-by-age interaction; unfortunately, gender was not determined for cormorants in this study. 
Table 3. Mean daytime (07.00-18.00 h) home range $(95 \%$ kernel) and core use areas $(50 \%$ kernel) of one adult and five immature (Imm) Double-crested Cormorants marked with Platform Transmitter Terminals in the Mississippi Alluvial Valley (MAV) of Arkansas, Louisiana, and Mississippi and the Upper Coastal Plain (UCP) of Alabama during summer (June to August) from 1999 to 2001. $\mathrm{N}=$ number of locations.

\begin{tabular}{lccccc}
\hline \hline Cormorant & Age class & Capture region & $\mathrm{N}$ & Home range $\left(\mathrm{km}^{2}\right)$ & Core use $\operatorname{area}_{\left(\mathrm{km}^{2}\right)}$ \\
\hline 034 & Adult & MAV & 69 & 12,646 & 262 \\
048 & Imm & MAV & 32 & 45,349 & 5,845 \\
049 & Imm & MAV & 44 & 42,792 & 2,817 \\
052 & Imm & UCP & 23 & 24,241 & 2,559 \\
053 & Imm & UCP & 25 & 43,599 & 6,334 \\
054 & Imm & MAV & 27 & 14,654 & 927 \\
Mean & & & 30,547 & 3,124 \\
SE & & & 6,197 & 1,019 \\
\hline
\end{tabular}

The summer home ranges reported here are nearly triple the size of the $95 \%$ home range $\left(4,646 \mathrm{~km}^{2}\right.$ for $2000 ; 8,119 \mathrm{~km}^{2}$ for $2001)$ and the $50 \%$ core use area $\left(820 \mathrm{~km}^{2}\right.$ for 2000; 1,206 $\mathrm{km}^{2}$ for 2001) reported by Dorr et al. (these proceedings) for eastern Lake Ontario cormorants $(\mathrm{N}=24)$. Again, the reason for this difference is unclear but may be due to the reasons noted above.

Similar to some other bird species (Nudds and Ankey 1982; Novoa et al. 2006; Rutz 2006), cormorants that migrated to

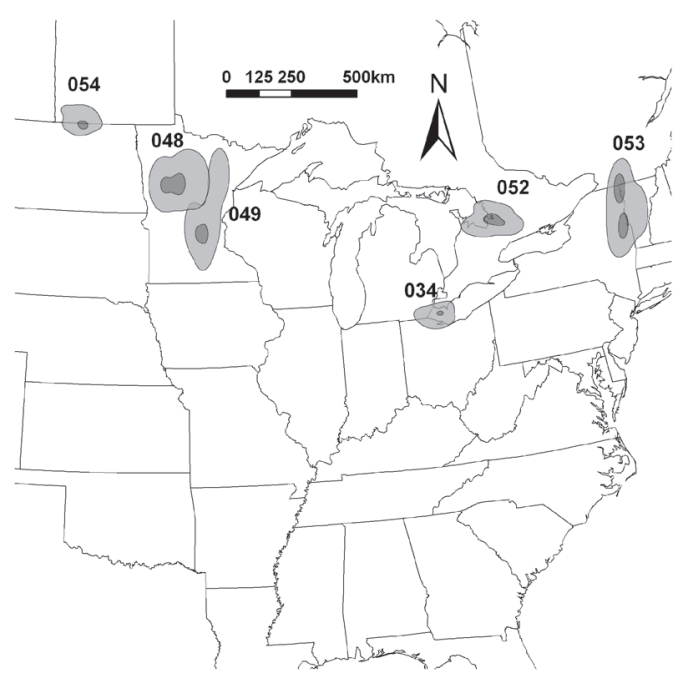

Figure 3. Summer (June to August) daytime (07.00-18.00 h) $\mathbf{9 5 \%}$ adaptive kernel home ranges (light shading) and $50 \%$ adaptive kernel core use areas (dark shading) of six Double-crested Cormorants marked with Platform Transmitter Terminals in the Mississippi Alluvial Valley of Arkansas, Louisiana, and Mississippi and the Upper Coastal Plain of Alabama from 1999 to 2001. Numbers represent bird identification. their summer grounds had larger summer than winter ranges. This increase in range size may be attributed to higher foraging and energetic requirements necessary to raise young during the summer. The high densities of prey confined in relatively small areas at aquaculture facilities provide a nearly ideal foraging habitat for piscivorous birds requiring limited energy expenditure to meet energetic requirements (Weseloh and Ewins 1994; Duffy 1995; King et al. 1995; King 1996; Glahn et al. 1999; Glahn and King 2004). These summer ranges encompassed much of the range of the Interior meta-population of cormorants described by Tyson $e t$ al. (1999) and Hatch and Weseloh (1999). Dolbeer's (1991) analysis of pre-fledged cormorant banding locations and their subsequent recoveries from the southeastern U.S. showed a similar pattern.

During the winter, most cormorants remained near aquaculture-intensive areas regardless of region, similar to cormorants tracked in earlier VHF telemetry studies (King et al. 1995; King 1996; Tobin et al. 2002; Dorr et al. 2004). Similar to these other studies, most cormorants tend to stay in one general region throughout winter if adequate food resources are available and their roosting sites are undisturbed. However, four $(10 \%)$ marked birds had large home ranges and were somewhat nomadic (see Methods). Although sample sizes were not adequate for analysis, a few cormorants ranged widely, similar to the few nomadic cormorants noted in earlier telemetry studies (King et al. 1995; King 1996). 
Future research should be conducted to better understand the summer movements of cormorants remaining in the southeastern U.S. throughout the year. GPS satellite telemetry should be used to determine whether long-term roost harassment and colony management has had an effect on cormorant ranges, habitat use, and activity budgets.

\section{ACKNOWLEDGMENTS}

B. S. Dorr, J. B. Harrel, M. Radford, S. J. Werner and B. S. Woodruff assisted with cormorant capture. S. Webb assisted with data analysis. M. E. Tobin and two reviewers provided comments on this manuscript.

\section{Literature Cited}

Chastant, J. E. 2008. Population characteristics of interior Double-crested Cormorants breeding across the southern border of Ontario. Unpublished M.Sc. Thesis, Mississippi State University, Mississippi State, Mississippi.

Dolbeer, R. A. 1991. Migration patterns of Double-crested Cormorants east of the Rocky Mountains. Journal of Field Ornithology 62: 83-93.

Dorr, B. S., D. T. King, M. E. Tobin, J. B. Harrel and P. L. Smith. 2004. Double-crested Cormorant movements in relation to aquaculture in eastern Mississippi and western Alabama. Waterbirds 27: 147-154.

Dorr, B. S., J. D. Taylor, II, S. J. Werner, D. T. King, J. F. Farquhar, I. M Mazzocchi and R. D. McCullough. (These proceedings.) Movements of satellite marked Double-crested Cormorants from a breeding colony managed by egg-oiling in Lake Ontario, USA. Waterbirds Special Publication 36:1.

Duffy, D. C. 1995. Why is the Double-crested Cormorant a problem? Insights from cormorant ecology and human sociology. Colonial Waterbirds 18 (Special Publication 1): 25-32.

Douglas, D. C. 2000. PC-SAS Argos Filter V2.4 Software Documentation. U.S. Geological Survey, Alaska Biological Science Center, Anchorage, Alaska.

Dunstan, T.C. 1972. A harness for radio-tagging raptorial birds. Inland Bird Banding News 44: 4-8.

Glahn, J. F. and A. R. Stickley, Jr. 1995. Wintering Double-crested Cormorants in the delta region of Mississippi: Population levels and their impact on the catfish industry. Colonial Waterbirds 18 (Special Publication 1): 137-142.

Glahn, J. F. and D. T. King. 2004. Bird Depredation. Pages 503-529 in Biology and culture of Channel Catfish. Developments in Aquaculture and Fisheries Science 34 (C. S. Tucker and J. A. Hargreaves, Eds.). Elsevier, Amsterdam, Holland.

Glahn, J. F., P. J. Dixon, G. A. Littauer and R. B. McCoy. 1995. Food habits of Double-crested Cormorants wintering in the delta region of Mississippi. Colonial Waterbirds 18 (Special Publication 1): 158-167.

Glahn, J. F., M. E. Tobin and J. B. Harrel. 1999. Possible effects of catfish exploitation on overwinter body condition of Double-crested Cormorants. Pages 107-113 in Symposium on Double-crested Cormorants: population status and management issues in the Midwest. Technical Bulletin No. 1879 (M. E. Tobin, Tech. Coord.). U.S. Department of Agriculture, Animal and Plant Health Inspection Service. Washington, D.C.

Glahn, J. F., D. S. Reinhold and C. A. Sloan. 2000. Recent population trends of Double-crested Cormorants wintering in the delta region of Mississippi: Responses to roost dispersal and removal under a recent depredation order. Waterbirds 23: 38-44.

Harestad, A. S. and F. L. Bunnell. 1979. Home range and body weight - A reevaluation. Ecology 60: 389402.

Hatch, J. J. and D. V. Weseloh. 1999. Double-crested Cormorant (Phalacrocorax auritus) in The Birds of North America (A. Poole and F. Gill, Eds.). The Academy of Natural Sciences, Philadelphia, Pennsylvania, and The American Ornithologists' Union, Washington, D.C.

Horne, J. S. and E. O. Garton. 2006. Likelihood crossvalidation versus least squares cross-validation for choosing the smoothing parameter in kernel homerange analysis. Journal of Wildlife Management 70 : 641-648.

Kernohan, B. J., R. A. Gitzen and J. J. Millspaugh. 2001. Analysis of animal space use and movements. Pages 125-166 in Radio tracking and animal populations (J. J. Millspaugh and J. M. Marzluff, Eds.). Academic Press, San Diego, California.

King, D.T. 1996. Movements of Double-crested Cormorants among winter roosts in the delta region of Mississippi. Journal of Field Ornithology 67: 205-211.

King, D. T., K. J. Andrews, J. O. King, R. D. Flynt, J. F. Glahn and J. L. Cummings. 1994. A night-lighting technique for capturing cormorants. Journal of Field Ornithology 65: 254-257.

King, D. T., J. F. Glahn and K. J. Andrews. 1995. Daily activity budgets and movements of winter roosting Double-crested Cormorants determined by biotelemetry in the delta region of Mississippi. Colonial Waterbirds 18 (Special Publication 1): 152-157.

King, D. T., M. Bur and M. E. Tobin. 2000. Capture and telemetry techniques for Double-crested Cormorants (Phalacrocorax auritus). Proceedings of Vertebrate Pest Conference 19: 54-57.

Littell, R. C., G. A. Milliken, W. W. Stroup, R. D. Wolfinger and O. Schabenverger. 2006. SAS for mixed models, $2^{\text {nd }}$ ed. SAS Institute Inc., Cary, North Carolina.

Nudds, T. D. and C. D. Ankney. 1982. Ecological correlates of territory and home range size in North American dabbling ducks. Wildfowl 33: 58-62.

Novoa, C., S. Dumas and J. Resseguier. 2006. Homerange size of Pyrenean Grey Partridges Perdix perdix 
hispaniensis during the breeding season. Wildlife Biology 12: 11-18.

Palmer, R. S. 1962. Handbook of North American Birds. Volume 1: Loons through Flamingos. Yale University Press, New Haven, Connecticut.

Rodgers, A. R., A. P. Carr, L. Smith and J. G. Kie. 2005. HRT: Home Range Tools for ArcGIS. Ontario Ministry of Natural Resources, Centre for Northern Forest Ecosystem Research, Thunder Bay, Ontario.

Rudstam, L. G., A. J. VanDeValk, C. M. Adams, J. T. H. Coleman, J. L. Forney and M. E. Richmond. 2004. Double-crested Cormorant predation and the population dynamics of Walleye and Yellow Perch in Oneida Lake. Ecological Applications 14: 149-163.

Rutz C. 2006. Home range size, habitat use, activity patterns and hunting behavior of urban-breeding Northern Goshawks Accipiter gentilis. Ardea 94: 185202.

SAS Inc. 2004. SAS/STAT 9.1 Users' guide. Cary, North Carolina.

Service Argos, Inc. 2001. Argos Users' Manual. Service Argos, Inc., Largo, Maryland. <http://www.argossystem.org/manual/>. Accessed 21 November 2011.

Schoener, T. W. 1968. Sizes of feeding territories among birds. Ecology 49: 123-141.

Tobin, M. E., D. T. King, B. S. Dorr, S. J. Werner and D. S. Reinhold. 2002. Effect of roost harassment on cormorant movements and roosting in the delta region of Mississippi. Waterbirds 25: 44-51.

Tyson L. A., J. L. Belant, F. C. Cuthbert and D. V. Weseloh. 1999. Nesting populations of Double-crested Cormorants in the United States and Canada. Pages 17-25 in Symposium on Double-crested Cormorants: population status and management issues in the Midwest. Technical Bulletin No. 1879 (M. E. Tobin, Tech. Coord.). U.S. Department of Agriculture, Milwaukee, Wisconsin.

USDA (United States Department of Agriculture). 1999. Catfish production. National Agricultural Statistics Service, Washington, D.C.

VanDeValk, A. J., C. M. Adams, L. G. Rudstam, J. L. Forney, T. E. Brooking, M. Gerken, B. Young and J. Hooper. 2002. Comparison of angler and cormorant harvest of Walleye and Yellow Perch in Oneida Lake, New York. Transactions of the American Fisheries Society 131: 27-39.

Weseloh, D. V. and P. J. Ewins. 1994. Characteristics of a rapidly increasing colony of Double-crested Cormorants (Phalacrocorax auritus) in Lake Ontario: Population size, reproductive parameters and band recoveries. Journal of Great Lakes Research 20: 443-456.

Worton B. J. 1989. Kernel methods for estimating the utilization distribution in home range studies. Ecology 70: 164-168. 